\title{
BUSINESS AND INDUSTRY
}

\section{General}

158 ASIAN INDUSTRY: The leading business monthly. Far East Trade Press Ltd, 1908, Princes Building, Des Voeux Road, Central, Hong Kong. 12. Controlled circulation. Gratis.

Business and trade features and articles for and about the region.

159 ASIAN MANUFACTURING: Formerly FAR EAST ENGINEER. Far East Trade Press Ltd, 1908, Princes Building, Des Voeux Road, Central, Hong Kong. 12. n.a.

Feature articles. News review, new products and processes.

160 BUSINESS ASIA: Weekly Report to Managers of Asia/Pacific Operations. Business International, A sia/Pacific Ltd, 301, Asian Hou se, One Henessey Road, Hong Kong, PO Box 385. 52. Annual H $\$ 1,296$.

Reports.

161 BUSINESS WEEKLY. Business Publications, Ring Road West, PO Box 2351, Accra, Ghana. 52. Annual £3.

Newspaper devoted to trade, commerce and industry, particularly from the point of view of a developing country.

162 CHEMICAL IN DUSTRY NEWS - see Engineering, Chemical Engineering

163 COIR: The leading quarterly journal on coir and coir goods. Coir Board, Cochin 16. 4. Annual 1 .

News items and articles from the coir industry.

164 COOPERATOR. National Cooperative Union of India, 72, Jorbagh, New Delhi 3. 24. Annual §1.

Articles concerning cooperatives.

165 ECONOMIC AND BUSINESS REVIEW: A National Abstract of Economic, Business and Industrial Affairs. S. S. Mohan, 31/13, East Patel Nagar, New Delhi, India. 6. Annual £1.25. 
166 GHANA ECONOMIC REVIEW. PO Box 5743, Accra. 1. n.a. Annual report "on the state of Ghana's economy and to provide opportunity for enterprises in the various sectors of the economy to review their performance and to re-assess their achievements and prospects."

167 HONG KONG REPORT. The Printing Department, 81 - 115, Java Road, North Point, Hong Kong. 1. Single issue H \$12.50.

Report on Hong Kong. Employment, financial structure, industry and trade, education etc.

168 INDIAN FARM MECHANIZATION - see Agriculture

169 INDIAN INDUSTRIES. 12, Bazlulla Road, Madras 17. 12. Annual £3.

A monthly on engineering and business management.

170 INDIAN JOURNAL OF INDUSTRIAL MEDICINE - see Medical

Sciences, General

171 THE INDIAN OIL AND SOAP JOURNAL - see Chemistry

172 INDIAN STANDARDS INSTITUTION BULLETIN. Indian Standards Institution, Manak Bhavan, 9, Bahadur Shah Zafar Marg, New Delhi 1, India. 12. Annual £3.75.

Articles on standards of manufactured goods.

173 INDUSTRIAL BULLETIN. Accounts Officer, Directorate of Industries, Sachivalaya Annexe, Bombay 32. Directorate of India, Government of Maharashtra. 12. Annual Rs 6.

Articles on industry in India.

174 INSTRUMENTS IN DIA: Official Organ of the All India Manufacturers and Dealers Association. All India M \& D Association, A - 32, Navyug Niwas, Lamington Road, Opp. Minerva Cinema, Bombay 7. 12. Annual Rs 20 .

"Devoted to instruments and instrumentation in India."

175 JOURNAL OF INDUSTRIAL ENGINEERING - see Engineering, General

176 JOURNAL OF SCIENTIFIC AND INDUSTRIAL RESEARCH - see Science

177 MADRAS JOURNAL OF CO-OPERATION: The Official Journal of Tamil Nadu Cooperative Union. Tamil Nadu Cooperative Union Buildings, Madras 9. 12. Annual Rs 10.

"Sceks to carry the message of the cooperative movement to all sections of the people and to promote a more earnest discussion of problems of cooperative and economic development. It also seeks to work for the establishment of a dynamic cooperative sector in the national economy." 


\section{Business and Industry, General}

178 OIL AND COAL NEWS: The Fortnightly Journal of Industry and Commerce. D - 34, South Extension, Part 1, New Delhi - 49, India. 26. Annual Rs 200.

179 PACKAGING INDIA: Journal of the Indian Institute of Packaging. Indian Institute of Packaging, 254 - C, Dr. Annie Besant Road, Prabhadevi, Bombay 25DD. 4. Annual £3.

Articles and features on packaging. Institute news, etc.

180 PESTICIDES - see Agriculture

181 PRODUCTIVITY: Quarterly Journal of National Productivity Council of India. National Productivity Council of India, 38, Golf Links, New Delhi 3. 4. Annual $£ 1$.

Contains "articles and suggestions for improvement of productivity in industry and other sectors of the national economy, also Theory and Globa]: Analysis, etc."

182 RESEARCH AND INDUSTRY. Publications \& Information Directorate, Hillside Road, New Delhi 12. The Council of Scientific \& Industrial Research, New Delhi. 4. Annual £1.50.

Publishes scientific studies on aspects of research and industry, with an economic bias.

183 SINGAPORE TRADE AND INDUSTRY. 422, Thomson Road, Singapore 11. Trade Division, Singapore Ministry of Finance and the Economic Development Board. 12. Single issue $\$ 2$.

"The Republic's foremost Business Review." Reports and news.

184 STEAM AND FUEL USERS JOURNAL - see Heating, Refrigeration and Ventilation

185 TECHNICAL ASSOCIATION OF MALAYSIA - JOURNAL. Technical Association of Malaysia, No.46, Jalan 52/4, Petaling Jaya. 4. Single issue $\$ 2$.

Contains Association news and articles on various aspects of industry.

186 ZAMBIAN REVIEW :Incorporating THE ZAMBIAN FARMER. Associatel Reviews Ltd, Canada House, President Avenue, Ndola, Zambia, PO Box 717. 12. Annual K2.50.

Economic and industrial features, company news. Now includes as a supplement ZAM BIA FARMER, the official organ of the National Agricultural Marketing Board and the Virginia Tobacco Association of Zambia. 


\section{Commerce and Trade}

187 AFRASIAN MARKETS. Amalgamated Press, 41, Hamam Strcet, PO Box 325, Bombay - 1, India. 12. Annual - Africa, Asia, Australia, UK £2; Canada $\$ 8$.

"Monthly export trade journal reaching vital buying and distributing organisations throughout the world."

188 AVIATION DIRECTORY OF ASIA - see Aeronautics and Space Flight

189 CEYLON TRADE JOURNAL: Ceylon Products in Overseas Markets. Director of Commerce, PO Box 1507, Colombo. Department of Commerce. 12. Annual Rs 15.

Reviews and summaries, statistics.

190 COMMERCIAL INDEX - see Bibliographies

191 COMMERCE. Manck Mahal, 90, Vecr Nariman Road, Bombay - 20, India. 52. Annual - Asia US \$28; Africa 16 ; Australia $\wedge \$ 3 j$; UK $£ 16$.

Political, commercial and economic articles and comment, fcatures, reports, statistics and book reviews.

192 DEPARTMENT OF STATISTICS, KINGSTON - BULLETIN - sce Statistics

193 EAST AFRICAN REPORT ON TRADE AND INDUSTRY: Official Journal of the Kenyan Association of Manufacturers. News Publishers Ltd, Box 30339, Nairobi, Kenya. 12. Annual - East Africa Sh 36; elsewhere $\operatorname{Sh} 51$.

Includes KENYA EXPORT NEWS. News and features, reports, prices.

194 EASTERN METALS REVIEW - see Metallurgy

195 EASTERN TRADE GAZETTE. Eastern Trade Publications, 290, Upper Thomson Road, Singapore. 12. Single issuc 50 cents.

Newspaper format. Articles concerning trade and industry in Malaysia.

196 FOREIGN TRADE OF INDIA. Directorate of Commercial Publicity, Ministry of Foreign Trade, Government of India, Udyog Bhawan, New Delhi. 12. Annual 22.50 .

Cortains "authoritative information" on "opportunities for industrial collaboration and trade partnership" in India. Features on industry in India. 


\section{Business and Industry, Commerce and Trade}

197 FOREIGN TRADE REVIEW : Quarterly Journal of Indian Institute of Foreign Trade. Indian Institute of Foreign Trade, H - 24, Green Park Extension, New Delhi 16. 4. Annual £1.25.

198 GHANA TRADE JOURNAL. Business Publications, PO Box 2351, Accra, Ghana. 12. Annual Cedi 2.16.

Trade,commerce, industry and finance - news and features.

199 GUYANA BUSINESS. Guyana Business, Georgetown Chamber of Commerce, 156, Waterloo Street, Georgetown, Guyana. 4. Annual G $\$ 6$.

Articles on commerce and finance in the Caribbean region.

200 HONG KONG ENTERPRISE. Hong Kong Trade Development Council, Ocean Terminal, Kowloon, Hong Kong. 12. Controlled circulation. Gratis.

News, features, classified descriptions of manufacturers.

201 INDIAN ELECTRICAL CONTRACTOR AND TRADER - see Electricity and Electrical Engineering

202 INDIAN EXPORT TRADE JOURNAL: Incorporating the IMPORTER DIGEST and THE INDIAN MANUFACTURER. Sayajiganj, Baroda 5, India. 12. $£ 5$.

"A monthly export trade journal circulated among buying and distributing organisations throughout the world."

203 INDIAN EXPORTER AND IMPORTER. 12, Fort Chambers, Hamam Street, Bombay 1. 12. Annual £2.

International trade news and reports.

204 INDIAN JOURNAL OF COMMERCE: A quarterly of the Indian Commerce Association. Indian Commerce Association, Department of Commerce, Jivaji University, Gwalior. 4. Annual £3.

"Designed to contribute to the advancement of knowledge directly related to the theory and practice of commerce and management and aims at an objective coverage of contemporary Indian commercial and managerial problems through a authoratitive analysis of developments in the country in the form of research papers, etc." Book reviews.

205 INDIAN TRADE JOURNAL. Department of Commercial Intelligence and Statistics, Ministry of Foreign Trade, Calcutta. 52. Annual $\$ 60$.

Reports and official announcements.

206 INDUSTRIAL INDIA: The Official Organ of the All India Manufacturers' Organisation. United Asia Publications Pvt. Ltd, 12, Rampart Row, Fort, Bombay 1. $12+$ annual issue. Three years' subscription Rs 65.

"To promote Indian industries and to further the interests of Indian manufacturers and exporters." 
207 INTERNATIONAL TRADE REVIEW: Official organ of the Indian Council of Foreign Trade. Indian Council of Foreign Trade, Churchgate Chambers, First Floor, 5, New Marine Lines, Bombay 20 BR. 12. Single issue Rs 2.

Trade news and policies, with particular reference to engineering.

208 JAMAICA CHAMBER OF COMMERCE JOURNAL. Jamaica Chamber of Commerce, 7, East Parade, Kingston, Jamaica. 4. n.a.

Short reports of the Chamber's activities together with articles on trade, industry and commerce with specific reference to Jamaica.

209 JOURNAL OF INDUSTRY AND TRADE. Deputy Director, Di rectorate of Commercial Publicity, Ministry of Foreign Trade, New Delhi - 11, India. 12. Annual 1.40.

Articles, statistics. "Unless specifically mentioned, articles and statements do not necessarily reflect the policies and views of the Government of India."

210 LEATHER MARKETS - see Leather

211 MALAYSIAN TRADE REVIEW. Chinese Assembly Hall, Jalan Birch, Kuala Lumpur. 1. Annual M $\$ 4$.

Articles on trade in Malaysia.

212 MALTA TRADE STATISTICS. Department of Information, Valetta, Malta. Central Office of Statistics. 4. Annual $£ 1$.

213 MINISTRY OF AGRICULTURE AND LANDS, JAMAICA - COMMODITY BULLETIN. Agricultural Information Service, Kingston, Jamaica. Irregular. n.a.

Short economic histories of various commodities.

214 THE NIGERIA TRADE JOURNAL. Federal Ministry of Education, Yakubu Gowon Street, Lagos. 4. Single issue $12 \frac{1}{2} \mathrm{p}$.

Features, news, announcements, trade statistics.

215 SIERRA LEONE TRADE JOURNAL. (Canada) - Sierra Leone Embassy, 170, 19th Street, N.W, Washington 6, D.C.

(Elsewhere) - Sierra Leone High Commission, 33 Portland Place, London, W.1. Ministry of Information. 4. Canada \$1.50, Elsewhere $50 \mathrm{p}$.

"The only official trade journal in Sierra Leone."

216 THE TANNER - see Leather

217 TANZANIA TRADE AND INDUSTRY. Public Relations Section, Ministry of Commerce and Industries, PO Box 234, Dar es Salaam, Tanzania. 4. Single issue 10p.

Notes, features, statistics. 